\title{
BCL10 Gene
}

National Cancer Institute

\section{Source}

National Cancer Institute. BCL10 Gene. NCI Thesaurus. Code C24259.

This gene is involved in the promotion of apoptosis. 